\title{
Mamminasata BRT User Trip Characteristics for the Design of Demand Modelling Method for a New BRT Line
}

\author{
Hitapriya Suprayitno ${ }^{1}$ and Verdy Ananda $\mathrm{Upa}^{1}$
}

\begin{abstract}
Indonesia started to develope largely the MRT line, especially the BRT. A new BRT Corridor implementation need a Passenger Demand Prediction. Thus, a Special BRT Passenger Demand Modelling Method for a New BRT Line need to be developed. This attempt needs a sufficient knowledges on the Existing BRT User Trip Characteristics. Mamminasata BRT User Trip Characteristics Survey were executed on Corridor 2 and Corridor 3, during morning peak hour. The result indicates that the BRTs are used mainly for schooling (50\%) and working $(50 \%)$ trips, the BRT passengers are the previous public transport $(\mathbf{7 6 \%})$ and motorcycle $(24 \%)$ users. The trip origin zone is extended $3 \mathrm{~km}$ to the left and to the right of the BRT corridor, while the trip destination zone is extended $1.5 \mathrm{~km}$ to the left and to the right of the BRT corridor. The embarking connecting trip modes are dominated by motorcycle $(51 \%)$, public transport $(19 \%)$ and becak (18\%), while the alighting connecting trip modes are dominated by walking trip (71\%).
\end{abstract}

Keywords — bus rapid transit, trip characteristics, previous mode, influence area, connecting trip characteristics.

Abstrak-Indonesia telah mulai membangun Angkutan Masal Cepat dengan luas, terutama BRT. Implementasi Koridor BRT Baru membutuhkan suatu Prediksi Permintaan Penumpang. Dengan demikian, suatu Metoda Pemodelan Permintaan Penumpang Khusus bagi BRT Koridor Baru perlu untuk dibangun. Upaya ini membutuhkan pengetahuan yang cukup tentang Karakteristik Perjalanan Pengguna BRT Yang Ada. Survei Karakteristik Perjalanan Penumpang BRT Mamminasata telah dilakukan untuk BRT Mamminasata Koridor 2 dan Koridor 3, pada Jam Puncak Pagi. Hasil Survei tersebut menunjukkan bahwa BRT pada Jam Puncak Pagi terutama digunakan untuk Perjalanan Kerja (50\%) dan Perjalanan Sekolah (50\%). Para Penumpang BRT tersebut sebelumnya adalah Pengguna Angkutan Umum (76\%) dan Pengguna Sepeda Motor (24\%). Zona Asal pengguna BRT merupakan daerah $3 \mathrm{~km}$ disebelah kiri dan kanan Koridor BRT, sedangkan Zona Tujuan pengguna BRT merupakan daerah $1,5 \mathrm{~km}$ dikiri dan dikanan Koridor BRT. Moda Penghubung yang digunakan sebelum menaiki BRT didominasi oleh moda sepeda motor (51\%), angkutan umum (19\%) dan becak (18\%). Sedangkan Moda Penghubung setelah turun dari BRT didominasi oleh moda jalan kaki (71\%).

Kata Kunci-bus rapid transit, karakteristik perjalanan, moda sebelumnya, daerah pengaruh, karakteristik perjalanan penghubung.

\section{INTRODUCTION}

$\mathrm{M}$ ass Rapid Transit (MRT) started to be largely developed in Indonesia. For first MRT implementation, the most popular and might be the most appropriate mode for Indonesia are the Commuter Train operating on the Existing Railway Network and the Bus Rapid Transit (BRT). The BRT has implemented, among others, in Jakarta as Trans Jakarta - 12 corridors, in Yogyakarta as Trans Jogja -8 corridors, in Semarang as Trans Semarang - 4 corridors, in Bandung as Trans Metro Bandung - 5 corridors, in Denpasar as Trans Sarbagita - 2 corridors, in Makassar as Trans Mamminasata - 3 corridors [2], [4], [8]-[13]. The BRT implementation are normally started by developing a BRT Master Plan consists of several BRT Corridors, which is then implemented step by step, one by one. Thus, BRT Passenger Demand Prediction is very important.

Under Presidential Decree 55/2011, Mamminasata is designated as a Metropolitan City covering Makassar, Maros, Sungguminasa, and Takalar. Makassar City, together with the surrounding area, has developed a BRT Master Plan, the Trans Mamminasata, consists of 11 Corridors. Among those 11 corridors, at present 3 BRT

${ }^{1}$ Hitapriya Suprayitno and Verdy Ananda Upa are with Department of Civil Engineering, Faculty of Civil engineering and Planning, Institut Teknologi Sepuluh Nopember, Surabaya, 60111, Indonesia. E-mail: suprayitno.hita@gmail.com; verdy.ananda@gmail.com
Corridors are in operation : Corridor 2 : Mall Panakkukang - Mall GTC, Corridor 3 : Airport Junction - Palangga Terminal, and Corridor 4 : Daya Terminal Maros Terminal. The next implementation is the Corridor 1: Airport Junction - Mall GTC. Thus Passenger Demand Prediction is needed.

A BRT Line operate only on a certain corridor. The go itinerary and the go-back itinerary not necesserally always the same. Thus, the the modelling area cover only A Strip Area along the Corridor. The method developed by Ministry of Transport is not very appropriate [14]. Special Passenger Demand Modelling Method for the New BRT Line need to be developed. It generate two basic important questions. How large is the BRT Influence Area ? Who are the user of the BRT ? Wether the present BRT user are only the previous public transport user ? Or the Public Transport User and the Motorcycle user ? Or maybe included the other mode user. Thus, identifying the BRT User Trip Characteritics related to those Main Questions is vital.

This paper present the research result on identifying the Existing BRT Users Trip Characteristics needed for the Design of BRT Passenger Demand Modelling Method for a New BRT Line.

\section{LITERATURE REVIEW}

Transport Modelling basically consist of 4 steps : 1 . trip generation (trip production and trip attraction) - well known as TG, 2. modal split - well known as MS, 3. trip 
distribution - well known as TD and 4. trip assignment well known as TA [3], [5], [6], [7]. Due to the variety of problem faced, practicality reason and the modelling technic development, nowadays we know three basic different modelling types : direct model, conventional model, unconventional model. Each modelling type has its own disadvantage and advantage [5], [6], [7]. Concerning the 4 Steps Modelling Sequence, in general we know 4 sequence types. Type 1 : TG/MS - TD - TA Type 2 : TG - MS - TD - TA. Type $3:$ TG - TD/MS TA. Type $4:$ TG - TD - MS - TA [7].

These two different types of Transport Modelling, combined each other, can give the most appropriate Modelling Method for a certain case. Different case need different combinaison [1], [5], [6], [7].

Special method to predict Public Transport Passenger Demand has been formalized by Directorate General of Land Transport. The Passenger Demand is a function of potential population to do trip, number of vehicle posession and private vehicle occupancy. The passenger demand is calculated for each bus stop. The influence area cover a strip of $800 \mathrm{~m}$ width along the bus line corrridor [14].

\section{METHOD AND DATA COLLECTION}

Main questions on the Demand Modelling Method Design for a New BRT Line are related to the modelling type (direct model, conventional model or unconventional model), the modelling step sequence (type 1 , type 2 , type 3 or type 4 ), the traffic zone definition and the others. The answer to these questions are related to the BRT User Trip Characteristics. The Main Characteristics are concerning : the trip purpose, the previous modes used before the operation of the BRT, the BRT Influence Area (how far is the origin point from the embarking BRT shelter and how far is the destination points from the alighting BRT shelter), the mode used before embarking and after alighting the BRT. More than that, certain Trip Characteristics were also noted, i.e the distribution of embarking passenger and alighting passenger along the BRT Shelters, together with the on-board passenger distribution by segment along the BRT Corridor.

This research is a prerequisite work to calculate BRT Passenger Demand Prediction for BRT Mamminasata Corridor 1 : Airport Junction - Mall GTC. At present there are 3 Mamminasata BRTs in operation : the Corridor 2 : Mall Panakukang - Mall GTC, Corridor 3 : Airport Junction - Palangga Terminal, Corridor 4 : Daya Terminal - Maros Terminal. BRT Corridor 2 and Corridor 3 were taken a samples for identifying the BRT User Trip Characteristics, since these two corridors pass through the city center area. The Corridor 3 is started from the Airport Junction; the same as the Corridor 1. While the Corridor 2 is ended in Mall GTC; the same as the Corridor 1. The Existing Mamminasata BRT Network is presented in Figure 1 below.

Survey were executed during morning peak hour in July 2016. A sample of 20 passengers were taken for each direction. It means, in total, a sample of 80 passengers have been gotten. The survey has been done in four days. The BRT Users Trip Characteristics collected are : the trip purpose; the previous modes used before the BRT in operation; the connecting trip characteritics before embarking - the embarking shelter, the origin point, the origin point distance, the mode used; and the connceting trip characteristics after alighting the alighting shelter, the destination points, the destination point distance, the mode used.

\section{ANALYSIS}

Survey has been finished, the data collected were analyzed to produced several keypoints characteristics needed for developing the BRT Passenger Demand Modelling Method. The keypoints characteristics are the trip purpose, the previous modes before the existence of the BRT, the connecting trips - distance and modes used. Two other characteristics were added, i.e. embarking alighting distribution and the on-board passenger distribution along the BRT corridor. Those keypoints characteristics are presented as follow.

\section{A. Trip Purpose}

The survey sample indicate that the BRT Corridor 2 and the BRT Corridor 3 in the morning peak hour are practically used only by the Schooling Trip at $50 \%$ and the Working Trip at 50\%. Those two are Regular Trip type. It can be concluded that the BRT, in the morning peak hour are used by the Regular Passenger. The morning peak hour ridership can be stated as stable. The survey data are presented in Table 1 .

\section{B. Previous Mode Used before the BRT Operation}

Concerning the Previous Mode Used before the BRT Operation, the survey data indicate that $76 \%$ of the sample used other public transports and $24 \%$ of the sample used motorcycle. This fact shows that the BRT is capable to shift the Motorcycle Mode to the BRT Mode. This will influence the Demand Modelling Method. The Demand Modelling survey can not be concentrated merely on the Public Transport User. The Motorcycle User has to be surveyed also. The survey data is presented in Table 2.

\section{Connecting Trip Characteristics}

For developing a Modelling Design, the BRT Influenced Area and Connecting Modes need to be identified. These all are indicated by Connecting Trip Characteristics, either the Embarking Connecting Trip and Alighting Connecting Trip. The Embarking Connecting Trip Distance will influence the extend of Trip Production Area for the BRT Passenger. The Alighting Connecting Trip Distance will influence the extend of the Trip Attraction Area for the BRT Passenger. The Connecting Modes is also important to be noted.

\section{1) Connecting Trip Characteristics - Before Embarking}

Survey on the Before Embarking Connecting Trip Characteristics indicate that Distance between Point of Origin to the Embarking BRT Shelter vary from $0-3$ $\mathrm{km}$. Most the trips, $48 \%$ of total sample, have accessing distances between $1-2 \mathrm{~km}$, and $36 \%$ of sample have aceesing distance between $0-1 \mathrm{~km}$. Concerning the accessing mode used by the passengers, $51 \%$ of them use motorcycle, $19 \%$ use public transport and $18 \%$ use becak. This indicate that the influence area for embarking extend up to $6 \mathrm{~km}$ wide strip along the corridor, with $4 \mathrm{~km}$ wide strip as the Main Influence 
Area. This Strip Area of $4 \mathrm{~km}$ wide, along the corridor, is the Main Trip Production Area for the Existing BRT Corridor 2 and Corridor 3. The survey result data are presented in Table 3 and Table 4 below.

\section{2) Connecting Trip Characteristics - After Alighting}

Survey on the After Alighting Connecting Trip Characteristics indicate that Distance between Point of Destinantion to the Alighting BRT Shelter vary from $0-$ $1.5 \mathrm{~km}$. Most the trips, $70 \%$ of total sample, have acessing distances between $0-0.5 \mathrm{~km}$, and $21 \%$ of sample have accesing distance between $0.5-1 \mathrm{~km}$. Concerning the connecting mode, $71 \%$ walk, $18 \%$ use becak and $11 \%$ use public transport. This indicate that the influence area for alighting extend up to $3 \mathrm{~km}$ wide strip along the corridor, with $2 \mathrm{~km}$ wide strip as the main influence area. This Strip Area of $2 \mathrm{~km}$ wide, along the corridor, is the Main Trip Attraction Area for the Existing BRT Corridor 2 and Corridor 3. The survey result data are presented in Table 5 and Table 6.

\section{Sample Embarking and Alighting Distribution.}

Sample data on embarking and alighting points indicate the following characteristics of embarking and alighting distribution. The embarking points for the two corridors in two directions are dominated by shelters which are located closed to residential area. The embarking points practically always located on shelters located not far from the BRT departure point. On the other hand, the alighting points practically distributed on shelters which are closed to or even next to the office, school and university area. The alighting points practically always located on shelters a bit far from the BRT departing point or closed to the BRT end point.

\section{E. On-Board Sample Passenger Distribution along Corridor Segments}

On-Board Sample Passenger Distribution along the Corridor Segments is also important to be noted. These characteristics can be used as a comparaison data to the Passenger Demand Modelling Result. Characteristics presented are based on Sample Passenger, which is 20 passenger for each Direction of each Corridor. The OnBoard Passenger Distribution along segment are presented for each Corridor.

\section{1) On-Board Sample Passenger Distribution along Segments - Corridor 2}

Passenger Distributions along Segments in Corridor 2 are similar for both directions. The distribution is heavy in the first segments and is light in the last segments. The biggests number of passenger happen between Shelter SMA 1 - Shelter Mall Ratu Indah for the First Direction (Mall Panakkukang - Mall GTC) and between Shelter Losari - Shelter Karebosi for the Second Direction (Mall GTC - Mall Panakkukang). Those two strips are located in Makassar CBD Area. The Passenger Distribution are presented in Figure 2 and Figure 3.

\section{2) On-Board Sample Passenger Distribution along Segments - Corridor 3}

Passenger Distributions along Segments in Corridor 3 are similar for both directions. The distribution is heavy in the middle segments. The biggests number of passenger happen between Shelter Daya - Shelter Pendidikan for the First Direction (Airport Junction Palangga Terminal) and between Shelter UMI - Shelter STIMIK Dipanegara for the Second Direction (Palangga
Terminal - Airport Junction). Those two strips are located in Makassar CBD Area. The Passenger Distribution are presented in Figure 4 and Figure 5.

\section{CONCLUSION}

The research objective has been fullfilled. Several key conclusions, concerning the Mamminasata BRT Corridor 2 and Corridor 3 User Trip Characteritics, can be presented as below:

1. The BRT is largely used by school trip and working trip in the morning peak hour. The morning peak hour passengers practically are all regular passenger.

2. The BRT Passenger are approximately consists of $76 \%$ of previous public transport users and $24 \%$ of previous motorcycle users.

3. The Trip Production Zone is a Strip of $6 \mathrm{~km}$ wide along the Corridor Line, with $84 \%$ of Production originated from a Strip of $4 \mathrm{~km}$ wide.

4. The Trip Attraction Zone is a Strip of $3 \mathrm{~km}$ wide along the Corridor Line, with $92 \%$ of trips have destinations on a Strip of $2 \mathrm{~km}$ wide.

5. The main Connecting Mode for Embarking are motorcycle at $51 \%$. While the share of other modes are public transport at $19 \%$, becak at $18 \%$, walking at $9 \%$ and car at $4 \%$.

6. The main Connecting Mode for Alighting is mainly walking at $71 \%$. Becak and public transport are used by $18 \%$ and $11 \%$ respectively.

7. The embarkation is ditributed among the BRT shelters closed to the residential area.

8. The alightment is distributed among the BRT shelters closed to the destination points, such as : schools, campusses and offices.

These Mamminasata BRT User Trip Characteristics data have been largely sufficient to develop the Passenger Demand Prediction Method for a New BRT Line.

Similar surveys for for different MRT modes for different cities will be very useful and needed for the MRT Planning and Feasibility Study.

\section{ACKNOWLEDGEMENT}

This research is a prerequisite work to develop the Passenger Demand Prediction for the will be implemented BRT Mamminasata Corridor 1 : Airport Junction - Mall GTC.

\section{REFERENCES}

[1] R. Cervero, J. Murakami and M. Miller, "Direct Ridership Mode of Bus Rapid Transit in Los Angeles County. Working Paper UCB-ITS-VWP-2009-3.," Institute of Transportation Studies. University of California, Berkeley, 2009.

[2] C. Nugroho, "Aksesibilitas Halte dan Kualitas Pelayanan Trans Jogja dengan Keputusan Pengguna," Fakultas Ilmu Sosial. Universitas Negeri Yogyakarta, Yogyakarta, 2013.

[3] J. D. Ortuzar and L. G. Willumsen, Modelling Transport. Second Edition, New York: John Wiley \& Sons, 1994.

[4] J. v. Steijn, "Creating Feeder Bus Lines for Trans Jakarta BRT," Civil Engineering. University of Twente, Twente, 2014.

[5] H. Suprayitno, "Metoda Pemodelan Angkutan Barang Perkotaan - Kasus Kotamadya Surabaya," in Seminar II FTSPT II, Surabaya, 1999.

[6] H. Suprayitno, "Penyusunan Metoda Perhitungan Mode Distribusi Perjalanan Berbasis Data Volume Lalu Lintas pada Kasus Pembebanan All-or-Nothing," in Seminar Nasional Aplikasi Teknologi Prasarana Wilayah 2015, Surabaya, 2015. 
[7] O. Z. Tamin, Perencanaan dan Pemodelan Transportasi. Edis Kedua, Bandung: ITB, 2000

[8] Direktur Jenderal Perhubungan Darat, "Direktorat Jenderal Perhubungan Darat, Kementrian Perhubungan Republik Indonesia," 16 August 2002. [Online]. Available: http://hubdat.dephub.go.id/keputusan-dirjen/tahun-2002/423-skdirjen-no-687aj. [Accessed 25 July 2016].

[9] (2016, July) Wikipedia-Trans Semarang. [Online]. https://id.wikipedia.org/wiki/TransSemarang.

[10] (2016, July) Wikipedia-Trans Metro Bandung. [Online]. https://id.wikipedia.org/wiki/TMB.
[11] (2016, July) Wikipedia-Trans Sarbagita. [Online]. https://id.wikipedia.org/wiki/Trans_Sarbagita.

[12] (2016, July) Wikipedia-Trans Mamminasata. [Online]. https://id.wikipedia.org/wiki/Trans_Mamminasata.

[13] (2016, July) Wikipedia-Trans Jakarta. [Online]. https://id.wikipedia.org/wiki/Transjakarta.

[14] (2016, July) Wikipedia-Trans Jogja. [Online]. https://id.wikipedia.org/wiki/Trans_Jogja.

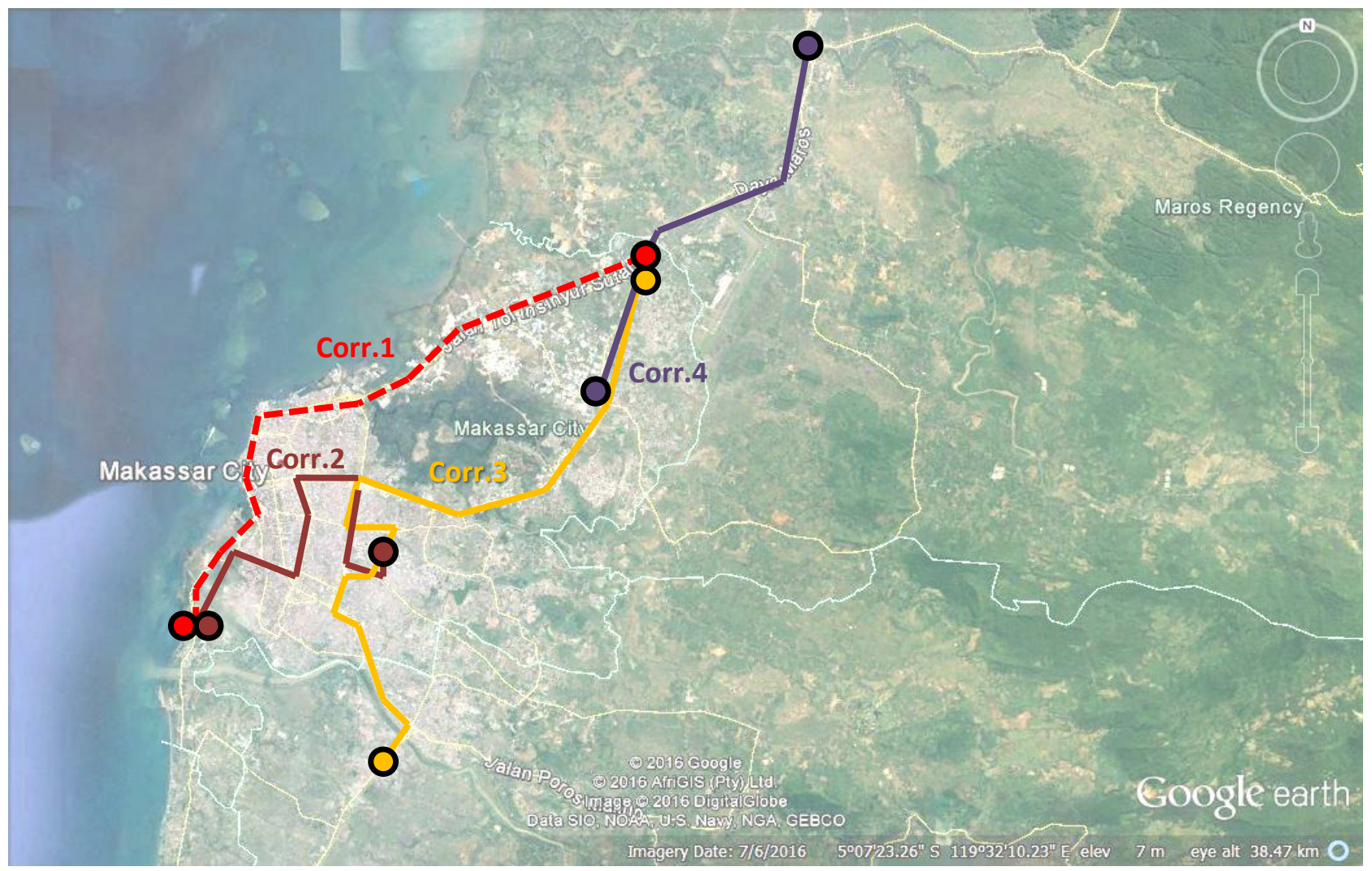

Figure 1. Existing Mamminasata BRT Network

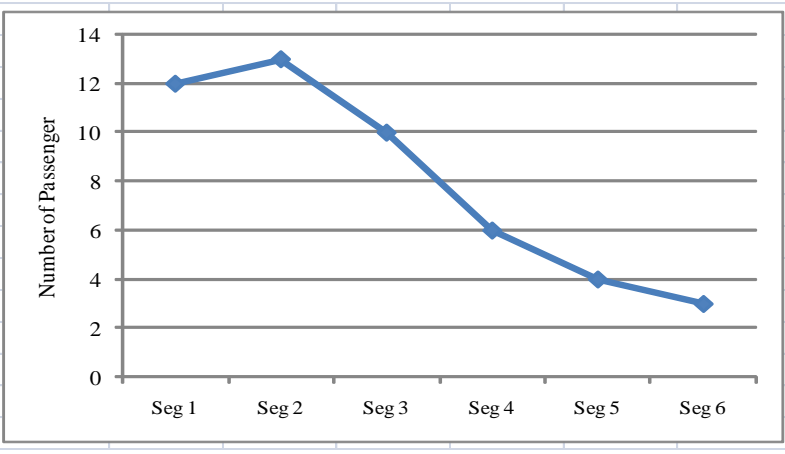

Figure 2. On-Board Sample Passenger Distribution - Corr 2 : Mall Panakkukang - Mall GTC

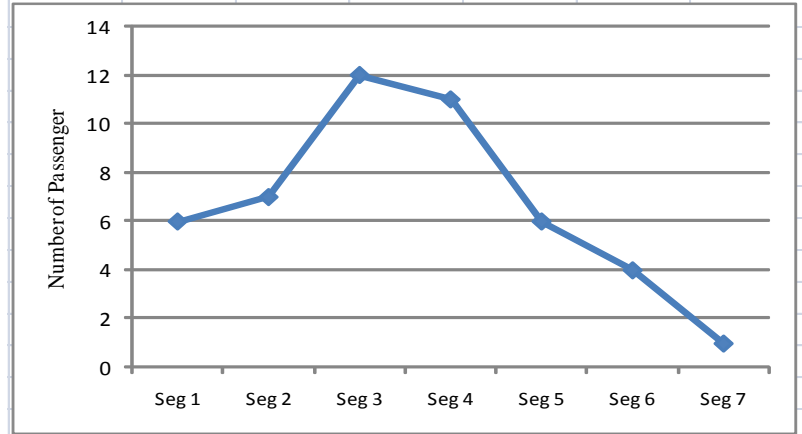

Figure 3. On-Board Sample Passenger Distribution - Corr 2 : Mall GTC - Mall Panakkukang 


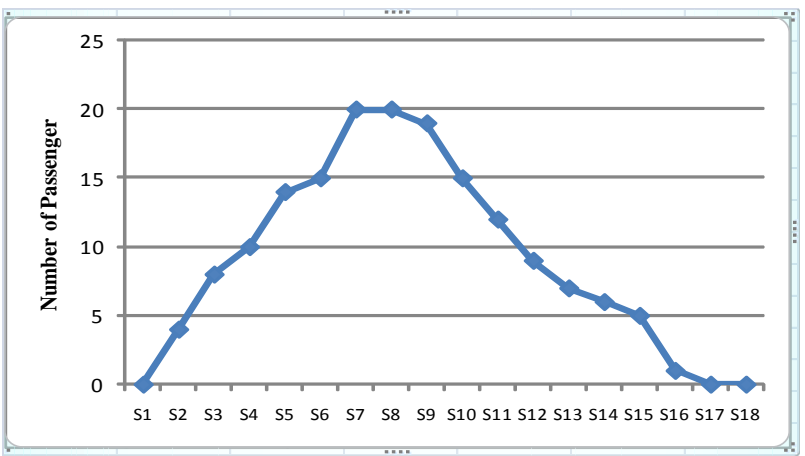

Figure 4. On-Board Sample Passenger Distribution - Corr 3 : Airport Junction - Palangga Terminal

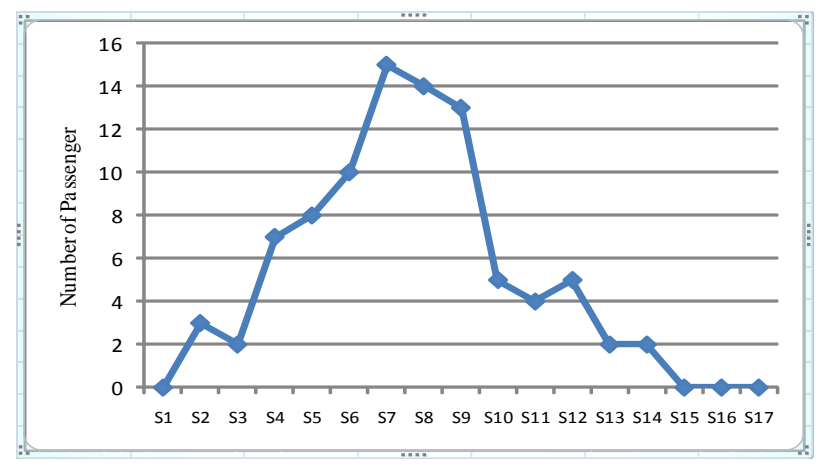

Figure 5. On-Board Sample Passenger Distribution - Corr 3 : Palangga Terminal - Airport Junction

TABLE 1.

TRIP PURPOSE

\begin{tabular}{cccccc}
\hline \hline No & Trip Purpose & Corridor 2 & Corridor 3 & Total & Percentage \\
\hline 1 & Schooling & 17 & 23 & 40 & $50 \%$ \\
2 & Working & 23 & 17 & 40 & $50 \%$ \\
\hline \hline
\end{tabular}

TABLE 2.

PREVIOUS MODES USED BEFORE THE BRT OPERATION

\begin{tabular}{cccccc}
\hline \hline No & Modes & Corridor 2 & Corridor 3 & Total & Percentage \\
\hline 1 & Public Transport & 29 & 32 & 61 & $76 \%$ \\
2 & Motorcycle & 11 & 8 & 19 & $24 \%$ \\
3 & Car & 0 & 0 & 0 & $0 \%$ \\
\hline \hline
\end{tabular}

TABLE 3.

DISTANCES BETWEEN THE ORIGIN POINT TO THE EMBARKING BRT SHELTER

\begin{tabular}{cccccc}
\hline \hline No & Distance & Corridor 2 & Corridor 3 & Total & Percentage \\
\hline 1 & $0.0-1.0 \mathrm{~km}$ & 12 & 17 & 29 & $36 \%$ \\
2 & $1.0-2.0 \mathrm{~km}$ & 20 & 18 & 38 & $48 \%$ \\
3 & $2.0-3.0 \mathrm{~km}$ & 8 & 5 & 13 & $16 \%$ \\
\hline \hline & Total & 40 & 40 & 80 & $100 \%$ \\
\hline \hline
\end{tabular}

TABLE 4.

MODES USED BEFORE EMBARKING THE BRT

\begin{tabular}{cccccc}
\hline \hline No & Modes & Corridor 2 & Corridor 3 & Total & Percentage \\
\hline 1 & Walking & 3 & 4 & 7 & $9 \%$ \\
2 & Becak & 1 & 13 & 14 & $18 \%$ \\
3 & Public Transport & 12 & 3 & 15 & $19 \%$ \\
4 & Motorcycle & 21 & 20 & 41 & $51 \%$ \\
5 & Car & 3 & 0 & 3 & $4 \%$ \\
\hline \hline
\end{tabular}

TABLE 5 .

Distances BetweEn the Destination POINT to the ALIGHTING BRT SHELTER

\begin{tabular}{cccccc}
\hline \hline No & Distance & Corridor 2 & Corridor 3 & Total & Percentage \\
\hline 1 & $0.0-0.5 \mathrm{~km}$ & 29 & 28 & 57 & $71 \%$ \\
2 & $0.5-1.0 \mathrm{~km}$ & 11 & 6 & 17 & $21 \%$ \\
3 & $1.0-1.5 \mathrm{~km}$ & 0 & 6 & 6 & $8 \%$ \\
\hline \hline
\end{tabular}


TABLE 6.

Modes Used AFTER Alighting THE BRT

\begin{tabular}{cccccc}
\hline \hline No & Mode & Corridor 2 & Corridor 3 & Total & Percentage \\
\hline 1 & Walking & 29 & 28 & 57 & $71 \%$ \\
2 & Becak & 11 & 3 & 14 & $18 \%$ \\
3 & Public Transport & 0 & 9 & 9 & $11 \%$ \\
\hline \hline
\end{tabular}

TABLE 7.

SAMPLE PASSENGER EMBARKING AND ALIGHTING DISTRIBUTION FOR CORRIDOR 2

\begin{tabular}{|c|c|c|c|c|c|c|}
\hline \multirow{2}{*}{ No } & \multirow{2}{*}{ BRT Shelter } & \multicolumn{2}{|c|}{ Mall P - Mall GTC } & \multirow{2}{*}{ BRT Shelter } & \multicolumn{2}{|c|}{ Mall GTC - Mall P } \\
\hline & & Embark & Alight & & Embark & Alight \\
\hline 1 & Mall Panakukang & 12 & - & Mall GTC & 6 & - \\
\hline 2 & SMA 1 & 5 & 4 & Trans Studio & 1 & - \\
\hline 3 & RS Pelamonia & 3 & 6 & Pantai Losari & 7 & 2 \\
\hline 4 & Mall Ratu Indah & - & 4 & Fort Rotterdam & - & 1 \\
\hline 5 & Rajawali & - & 2 & Karebosi & 5 & 10 \\
\hline 6 & Trans Studio & - & 1 & Masjid Raya & 1 & 3 \\
\hline 7 & Mall GTC & - & 3 & Masjid Al-Markaz & - & 3 \\
\hline 8 & & & & Mall Panakukang & - & 1 \\
\hline & Total & 20 & 20 & Total & 20 & 20 \\
\hline
\end{tabular}

TABLE 8 .

SAMPLE PASSENGER EMBARKING AND ALIGHTING DISTRIBUTION FOR CORRIDOR 3

\begin{tabular}{|c|c|c|c|c|c|c|}
\hline \multirow{2}{*}{ No } & \multirow{2}{*}{ BRT Shelter } & \multicolumn{2}{|c|}{ Airport - Palangga } & \multirow{2}{*}{ BRT Shelter } & \multicolumn{2}{|c|}{ Palangga - Airport } \\
\hline & & Embark & Alight & & Embark & Alight \\
\hline 1 & Airport & - & - & Palangga & - & - \\
\hline 2 & Bumi Permata & 4 & - & UnMuh & 3 & - \\
\hline 3 & Citra Sudiang & 4 & - & Arsip & - & 1 \\
\hline 4 & $\mathrm{KLH}$ & 2 & - & UIN & 5 & - \\
\hline 5 & Bulurokeng & 4 & - & LPMP & 1 & - \\
\hline 6 & Perhubungan & 1 & - & Mall Panakukang & 3 & 1 \\
\hline 7 & Daya & 5 & - & UMI & 6 & 1 \\
\hline 8 & STIMIK Tamalanrea & - & - & Gubernur & - & 1 \\
\hline 9 & Cokroaminoto & - & 1 & UIM & - & - \\
\hline 10 & Pendidikan & - & 4 & STIMIK Dipanegara & - & 1 \\
\hline 11 & STIMIK Dipanegara & - & 3 & Pendidikan & - & 8 \\
\hline 12 & UMI & - & 3 & RS Hasanuddin & - & 1 \\
\hline 13 & Bosowa & - & 2 & DAMRI & 2 & 1 \\
\hline 14 & Mall Panakukang & - & 1 & Perhubungan & - & 3 \\
\hline 15 & UNM & - & 1 & $\mathrm{KLH}$ & - & - \\
\hline 16 & UIN & - & 4 & Citra Sudiang & - & 2 \\
\hline 17 & UnMuh & - & 1 & Bumi Permata & - & - \\
\hline 18 & SMA 1 Gowa & - & - & Airport & - & - \\
\hline \multirow[t]{2}{*}{19} & Pallangga & - & - & & & \\
\hline & Total & 20 & 20 & Total & 20 & 20 \\
\hline
\end{tabular}

